ROZSAS, Jeanette. Kafka e a marca do corvo: romance biográfico sobre a vida e o tempo de Franz Kafka. São Paulo: Geração Editorial, 2009.

\title{
Kafka: de menino triste a conhecedor do mundo
}

\section{Claudia Cristina Maia*}

A 3 de julho de 1883, nascia, em Praga, um menino sensível, quieto e melancólico, mas que surpreenderia o mundo com o vigor e a pungência de uma literatura, que golpeia como um machado "o mar enregelado que temos dentro de nós" (Kafka, Cartas).

Em Kafka e a marca do corvo, Jeanette Rozsas narra, entre romance e biografia, as angústias e paixões da vida o maior escritor tcheco, talvez do século XX e de todos os tempos. O livro, dividido em sete partes, traz belas fotografias de Kafka, da família, dos amigos, das mulheres e, também, da bela cidade de Praga. Na introdução, "Praga e a Cidade Velha", descreve-se a paisagem da capital tcheca, o casario, as ruelas, os monumentos e a praça. "Depois que sua obra foi trazida a público nos meados do século XX, Praga e Kafka passaram a ser uma só entidade" (p. 16), como se o rosto do escritor se confundisse com a paisagem da qual nunca conseguiu se afastar.

A triste infância do menino Franz, marcada pela austeridade do pai, é narrada em sua crueza. O nascimento de Kafka não atende às expectativas de Hermann, pois ansiava por um filho robusto e barulhento. O menino, no entanto, franzino e silencioso, torna-se, com o tempo, uma criança tímida e triste. Após a morte do segundo filho, Hermann Kafka se mostra mais severo e duro. Com o crescimento de seus negócios, aproxima-se dos ricos comerciantes da cidade e se afasta do judaísmo quando sentimentos antissemitas crescem em Praga. De família pobre, o pai de Kafka se preocupava muito com sua ascensão social e assumir-se judeu, naquele contexto, poderia ameaçar seus planos. Por isso, ia à sinagoga apenas em datas muitos importantes.

Com a morte do terceiro filho, e cada vez mais autoritário e punitivo, passa a atemorizar ainda mais o menino. Em conversas com a mulher Julie, faz previsões para a vida do filho: "Franz não será ninguém. Não tem estofo, não tem coragem." (p. 34) Sempre criticado, Kafka fugia de sua presença, preferindo a solidão. A escola não ajudou muito, o professor era rígido e os colegas zombavam dele. Era bom aluno e apreciava os livros, mas não gostava do ambiente da escola. Foi assim que criou uma brincadeira que o protegeria dos olhares alheiros: "fingir que ninguém conseguia enxergá-lo" (p. 44), tornar-se "invisível", brincadeira que praticava sempre que desejava estar longe da tirania do pai, da censura do professor, das maldades dos colegas.

Depois da escola primária, pela qual passou com grande sucesso, no ginásio, Kafka começou a assumir suas próprias convicções, mesmo com a reprovação do pai. Nessa época, aderiu às ideias socialistas, tornou-se grande leitor de Nietzsche e planejou ser escritor, com o apoio de amigos. Seus primeiros escritos foram peças de teatro encenadas por suas irmãs nas festas de família. Em 1902, matricula-se no curso de Direito, mas continua a frequentar círculos intelectuais para discutir Literatura, Filosofia, Religião e Política. Esses encontros eram causa de grandes desavenças entre Kafka e o pai, desentendimentos que se acirravam cada vez mais, tornando a convivência entre os dois quase intolerável, o que fez com que o escritor pensasse muitas vezes em suicídio.

O texto de Jeanette Rozsas, escrito em linguagem simples, leva o leitor brasileiro a conhecer importantes momentos da vida de Kafka. Além das agruras da infância e da adolescência, tomamos conhecimento da angústia que foi para ele tornar-se escritor. O futuro de grande nome na literatura deveu-se em grande parte à amizade de Max Brod, um dos amigos com quem dividia discussões filosóficas nos cafés de Praga. Judeu como Kafka, Brod leu os primeiros originais de suas narrativas, 
vislumbrando o grande sucesso do amigo. Depois de formado e trabalhando como advogado, o autor de $A$ metamorfose escrevia suas narrativas nas horas de folga e nunca estava certo se deveria publicálas. Quanto a isso, sempre recebeu o apoio de Brod. Seu primeiro texto publicado foi Descrição de uma luta, na revista literária Hiperyon.

Os muitos diálogos da narrativa, com o pai, os amigos e as amadas, são reproduzidos das correspondências de Kafka, no intuito de oferecer ao leitor um relato o mais próximo possível do ambiente em que viveu o escritor. Os quatro últimos capítulos são os nomes das mulheres com que Kafka se relacionou: Felice, Julie, Milena e Dora. A partir daí, a narrativa se volta para a publicação de seus livros, para os envolvimentos amorosos e para as viagens que realizou na companhia de Brod, além dos anos que passou atormentado pela tuberculose e por ideias suicidas. Das quatro mulheres, Milena parece ter sido sua grande paixão; a ela estava estreitamente vinculado, mesmo depois do rompimento, sobretudo em virtude da literatura. Foi ela quem traduziu alguns de seus textos para o tcheco e a ela entregou sua Carta ao pai e os Diários. Com a doença já em estado avançado, Kafka já não escreve com a constância de antes e chega a pedir a Brod que destrua todos os seus escritos quando morrer, pedido ao qual o amigo se recusa a atender. Apesar de nunca ter sido religioso, depois de assistir uma companhia de teatro iídiche ainda em 1911, Kafka passa a se interessar pela história e tradição judaicas, interesse que foi crescendo no decorrer dos anos, sobretudo por influência de Dora Diamant, sua última companheira, que conheceu em 1923.

De família judeu-ortodoxa e grande conhecedora do hebraico, Dora foi, por assim dizer, o último amor de Kafka e com ela passou alguns meses em Berlim. Com a saúde já bastante abalada, ele volta a Praga e, depois, segue em companhia de Dora para a Áustria, a fim de se tratar, mas todo o esforço foram insuficientes para curá-lo. Kafka morre em 3 de junho de 1924 e é enterrado num cemitério judeu em Praga, cidade de "cujas garras só conseguiu se libertar por poucos meses" (p. 166), conclui o narrador. Ao final de Kafka e a marca do corvo, pode-se ler o "adeus emocionado" publicado por Milena Jesenká no jornal Národní Listy, três dias após a morte do escritor. Lúcido e emocionado, o adeus de Milena descreve bem o homem e o escritor Franz Kafka: "Seu conhecimento do mundo era vasto e profundo. Ele em si era um vasto e profundo mundo. [...] Como homem e artista, era tão infinitamente escrupuloso que se mantinha alerta mesmo onde outros, os surdos, sentiam seguros." (p. 168)

O livro de Jeanette Rozsas, com apresentação do crítico e também ficcionista Nelson de Oliveira, oferece ao leitor uma bela história, um testemunho ficcional maravilhoso do grande escritor que foi Kafka. No Epílogo, há informações sobre o destino dos outros personagens: os pais, as irmãs, os amigos e os amores, muitos deles vítimas do Nazismo. A maior parte da obra do escritor foi publicada após sua morte, graças à dedicação de Max Brod, que ignorou os testamentos em que Kafka expressa o desejo de ter sua obra destruída. Brod reuniu todos os textos que encontrou; alguns se perderam confiscados pelos nazistas. Rozsas também enfatiza o papel do grande crítico literário Otto Maria Carpeaux na divulgação da literatura de Kafka no Brasil. Carpeaux chegou a conhecer Kafka pessoalmente em Berlim, no ano de 1921, e cinco anos depois, recebeu de uma editora berlinense, como pagamento de algumas traduções, um exemplar da primeira edição de $O$ processo, livro do qual a editora tinha vendido apenas três exemplares. Em 1939, Carpeaux trouxe o livro para o Brasil e hoje

o raro exemplar encontra-se na Biblioteca Municipal Mário de Andrade, em São Paulo.

* Cláudia Maia é Doutoranda em Literatura Comparada no Programa de Pós-Graduação em Letras: Estudos Literários da FALE/UFMG. 